\title{
The Fig: Overview of an Ancient Fruit
}

\author{
Ed Stover ${ }^{1}$ and Malli Aradhya \\ USDA, ARS, National Clonal Germplasm Repository, One Shields Avenue, University of California, \\ Davis, CA 95616 \\ Louise Ferguson and Carlos H. Crisosto \\ Department of Plant Sciences, One Shields Avenue, University of California, Davis, CA 95616
}

Additional index words. Ficus carica, pollination biology, postharvest

\begin{abstract}
The genus Ficus includes species ranging in number from 600 to more than 1900, with most found in the tropics or subtropics and only a handful with fruits considered edible (reviewed in Condit, 1969). The cultivated fig, Ficus carica L., (Moraceae), is clearly of greatest importance as a source of human food. The fig fruit has long been associated with horticulture in the Mediterranean region (Zohary and Spiegel-Roy, 1975) and is considered to have been "first brought into cultivation in southern Arabia" (Storey, 1975). Wild or "nearly wild" figs are reported throughout much of the Middle East and Mediterranean region (De Candolle, 1886). Cultivated figs are reported to have become established across the Mediterranean region $\approx 6000$ years ago, reaching England by 500 CE (Ferguson et al., 1990). Interestingly, the fossil record shows a prehistoric distribution of Ficus carica across southern Europe (De Candolle, 1886).
\end{abstract}

\section{FIG PRODUCTION WORLDWIDE}

Fig is widely planted in door yards throughout the Mediterranean region (and similar climates), and is well adapted to drought and high temperatures. The Food and Agricultural Organization of the United Nations (FAO, 2006) estimates that figs are harvested from 427,000 ha, producing more than one million metric tons per year. Turkey produces $\approx 26 \%$ of the world's figs and, when combined with Egypt, Iran, Greece, Algeria, and Morocco, these top six producing countries account for $\approx 70 \%$ of the world's annual production. The United States ranks eighth, with $4 \%$ of global fig production in 2005 . Fourteen U.S. states produce figs commercially, but California produces $98 \%$ of the U.S. crop, on 5100 ha, but with a yield per hectare three times the global average.

\section{APPRECIATION FOR FIGS}

Historical works provide evidence of the sustained importance and appreciation of figs in the Mediterranean area. Pliny the Elder in his Natural History (Bostock and Riley, 1855) extolled "One hundred and eleven observations" on the fig. Among them, "This fruit invigorates the young, and improves the health of the aged and retards the formation of wrinkles," and (revealing just one more among many observations) "Mixed with axle-grease it (fig milk) removes warts." Among the most interesting comments is that of the prophet Mohammed indicating, "If I could wish a fruit brought to paradise it would certainly be the fig" (Condit, 1947). It is strange to think that this esteemed fruit is virtually unknown to most U.S. consumers, except as a brown paste inside distinctive fig cookies.

\section{THE FIG TREE}

Fig trees are deciduous, fast growing, and spreading in habit, so that they tend to be greater in width than in height. Plants from cuttings or seed typically grow into singletrunk trees with little training, but trees damaged by freeze or other injury, may resprout from roots with multiple trunks. The wood of fig trees is low in density and breaks easily. Branches have a pithy interior. Latex, which is irritating to human skin, is produced from all broken plant structures.

Tree height at maturity varies according to genotype and typically ranges from 3 to $10 \mathrm{~m}$. Fig trees are very plastic in form and can be pruned to many shapes and remain productive.

\section{STRUCTURE OF THE FIG FRUIT}

The fig "fruit" is a composite formed of a hollow shell of receptacle tissue enclosing hundreds of individual pedicellate drupelets that develop from the individual female flowers lining the receptacle wall, with a small scale-lined opening (called the ostiole or eye) at the distal end. The tiny flowers and even the initial prosyconium are so small that figs were once considered to bear fruit without ever forming flowers. This composite fruit is called a "syconium" (reviewed in Condit, 1947). The mature fruit of the edible fig has a somewhat tough skin, a whitish interior rind, and a sweet, gelatinous pulp comprised of the individual ripe drupelets. The seeds within the drupelets range from virtually nonexistent to subtly crunchy.

\section{FIG POLLINATION BIOLOGY AND ITS GENETIC BASIS}

In addition to having a distinctive fruit, the fig also has an interesting and distinctive pollination biology. Wild figs produce both functional male and female flowers within the syconium. Fruiting cultivars produce functional female flowers with abortive hermaphroditic flowers ringing the ostiole (Beck and Lord, 1988), but vary in their need for pollination.
The female flowers in edible figs are long styled and produce a much more succulent fruitlet, in contrast to female flowers in the short-styled monoecious wild-type figs (Fig. 1, Armstrong, 2006). It is proposed (Storey, 1975) that a mutation in the wild fig gave rise to the long-styled pistils/succulent fruitlet in the edible fig (Table 1). As either a pleiotropic effect or mutation in a tightly linked gene, the edible fig also displays a suppression of the androecium. Some socalled caprifigs are reported to be edible and have a more succulent fruitlet than typical caprifigs. We do not know of any studies that investigate the anatomic or genetic factors that result in these so-called edible caprifigs.

Four types of figs are described based on cropping/pollination characteristics. The type known as "common figs" requires no pollination to set a commercial crop. Botanists use the term "persistent" rather than "parthenocarpic," because the fig is not a true fruit. The other two types of edible fig are not persistent and require pollination to set the main crop of figs. Botanically, these nonpersistent types are classified as "cauducous" and are classed as Smyrna types (e.g., 'Calimyrna', 'Marabout', and 'Zidi') and San Pedro types (e.g., 'Dauphine', 'King', and 'San Pedro'). The San Pedro types are distinguished by setting a persistent early crop, known as "breba" fruit, but require pollination (called "caprification" in figs) to set the main crop.

The fourth type, caprifigs (goat figs), provides the source of pollen for commercial plantings of cauducous figs. Fig pollen is carried by a unique wasp (Blastophaga psenes L.), that has co-evolved with the fig. (Kjellberg et al., 1987). An important botanical component of this co-evolution is the protogynous nature of the caprifig, so that female flowers are receptive 6 to 8 weeks before anthers mature in the same syconium (Condit, 1932). Through this feature, wasps enter, pollinate, and oviposit a syconium that later has mature pollen as the next wasp generation emerges.

The blastophagas develop in caprifigs, which are kept separate from the figs to maximize control of pollination. Ripe caprifigs are cut and placed in bags or baskets in trees of the Smyrna and San Pedro-type figs, and are typically supplied at three times in regular intervals in May through June in California. The fig growers goal is for only one wasp to enter each fig. Excessive pollination increases fruit splitting. In addition, 


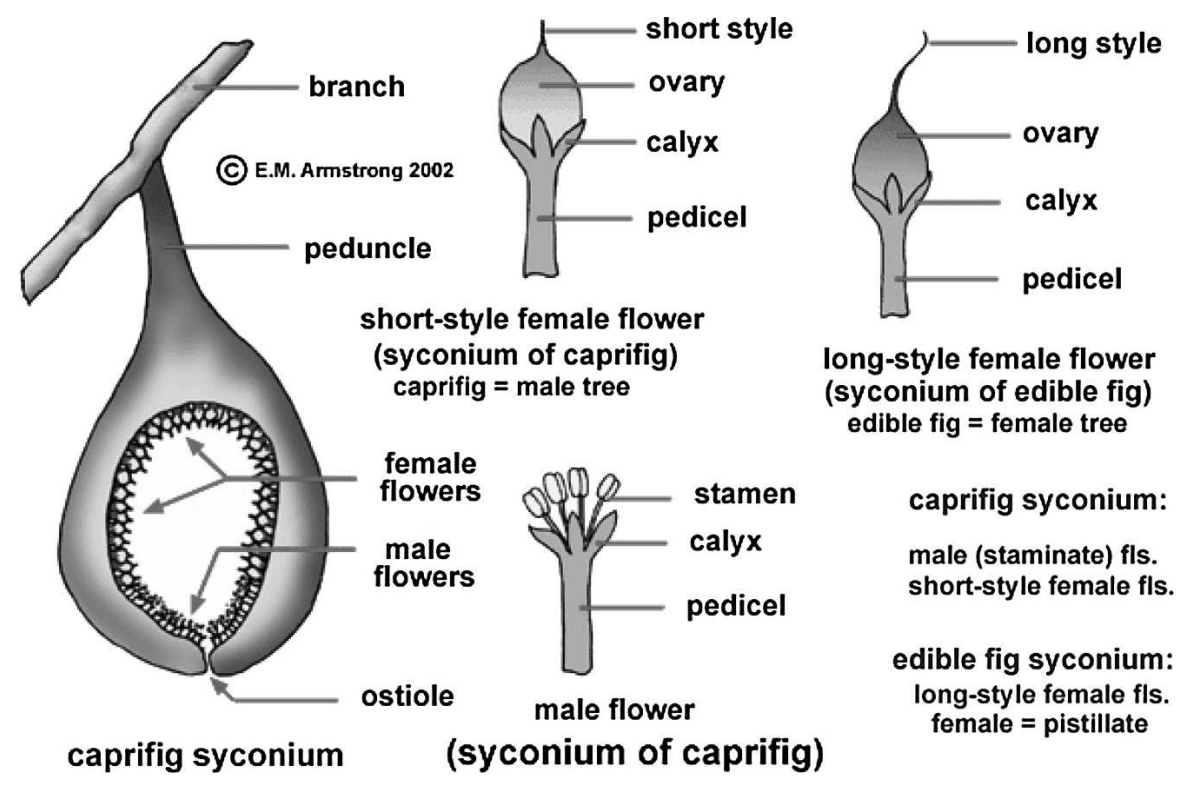

Fig. 1. Floral morphology in caprifigs and edible figs. (Figure used with permission, Armstrong, 2006)

Table 1. Percentage edible figs in progeny based on genotypes of pollen and seed parents (Storey, 1975).

\begin{tabular}{lcr}
\hline & \multicolumn{2}{c}{ Seed Parent } \\
\cline { 2 - 3 } Pollen parent & GA/GA & GA/ga \\
\hline GA/GA & $0 \%$ & $0 \%$ \\
GA/ga & $0 \%$ & $25 \%$ \\
ga/ga & $0 \%$ & $50 \%$ \\
\hline
\end{tabular}

$\mathrm{G}$ and $\mathrm{A}$ are closely linked loci.

$\mathrm{G}$, dominant allele for short-styled pistils; $\mathrm{g}$, recessive allele for long-styled pistils; A, dominant for functional androecium (and thus pollen); a, recessive allele suppressing androecium.

the incidence of internal defects incited by microorganisms is increased with the incidence of wasp entry.

\section{FIG CULTIVARS}

Naming of desirable fig cultivars is recorded as early as the fourth century BCE. In the first century ACE, Pliny lists 29 varieties of fig. De Candolle (1886) notes that the "cultivated forms [of figs] are numberless." Even after eliminating suspected synonyms, the most complete fig monograph (Condit, $1955)$ describes 607 named fruit-producing cultivars.

However, the California fig industry is largely based on five cultivars: Calimyrna (Sari Lop), Adriatic, Mission, Brown Turkey, and Kadota (California Fig Advisory Board, 2006; California Fresh Fig Growers Association, 2006). Fresh fig quality is greatest at full ripeness, but such soft figs are especially sensitive to damage (Chessa, 1997). Therefore, the balance between quality and even a modest shelf-life demands harvest at early ripeness (good color) in fresh figs for commercial sale. Even though most of world's figs are eaten fresh, their fragility has demanded that fresh figs are largely consumed where they are produced. Because of their high sugar content and stability, most fig exports are as dried fruit. Reflecting this fact, $94 \%$ of California fig production is dried or otherwise processed.

Of the cultivars described by Condit (1955), 78\% are common types, less than $4 \%$ are San Pedro types, and the remaining $18 \%$ are Smyrna types. Cultivars also vary in such traits as leaf morphology, plant vigor, fruit external and internal color, fruit flavor/ degree Brix/titratable acidity, seed characteristics, shape of fruit, skin thickness, ostiole diameter, and duration of fruit production. A small selection of the amazing diversity in fig cultivars, focusing primarily on commercial varieties, is described in Table 2.

\section{BREEDING FOR IMPROVED FIGS}

Virtually all fig cultivars did not arise through a planned breeding program. Beginning in 1908, efforts at fig improvement were begun in California. This became a sustained focus at the University of California at Riverside from 1928 to the 1980 s by Ira Condit and William Storey. Doyle and Ferguson (1997) of the University of California at Davis just released the 'Sierra' fig for drying and will soon release the 'Sequoia' fig, which is expected to find a place in fresh fig production. Other efforts are ongoing in the United States and other countries.

The stated focus of the California figbreeding effort has been development of 'Calimyrna'-like quality without the need for caprification and with a small ostiole (reviewed in Storey, 1975). This would eliminate the expense and also the uncertainty associated with the caprification process, such as the potential for too little pollination, excess pollination leading to splitting of many fruits (Crane and Blondeau, 1949), increased incidence of internal damage from pathogens introduced by blastophagas (Michailides et al., 1996) or other vectors (Schwaez, 1933), and potential associated food safety concerns (Doster et al., 1996). In fig breeding, it has been easy to select good maternal parents, because they presumably exhibit the qualities that the breeder is likely pursuing. The strength of California fig breeding has been the focus of identifying and developing improved caprifigs, and creating pollen parents that convey good fruit quality and the persistent trait, which eliminates the need for pollination. Key to this strategy was developing an understanding of the genetics of the persistent trait. Interestingly, it was found that the allele for persistence is dominant but is lethal in the ovule, and thus can only be conferred by the pollen parent (Table 3) (Saleeb and Storey, 1975). When the genetics of persistence and long styles/suppressed androecium are both considered, it becomes apparent that no more than $25 \%$ of the progeny will carry both of these traits.

\section{BREBA CROP VERSUS MAIN CROP}

Although San Pedro types are in part defined by the setting of a breba crop, some common figs will also produce brebas. Brebas are the first figs of the season, setting on wood from the previous year, and typically mature in June in the Central Valley of California. Some cultivars are grown because of their tendency to produce brebas (which tend to be larger than main crop figs), are relatively scarce on the market, and tend to get a high price as fresh fruit. The main crop is produced on the current season's wood, maturing fruit from August through November (in Winters, CA.) or even later in a warm year. Achievement of maturity in main crop fig fruits on a single tree is sequential, beginning with development of basal fruits and progressing toward the most distal fruits. This makes it necessary to harvest repeatedly in production of fresh fruits (Chessa, 1997), whereas figs for drying are typically collected from the ground in a single harvest for main crop figs (Obenauf et al., 1978).

\section{CULTIVATION OF FIG}

Fig is especially well adapted to Mediterranean environments, with cool winters and hot, dry summers, but can be grown in more humid regions, including the tropics and subtropics, where they will experience more fruit splitting and disease. A chilling requirement to break dormancy is typically around 300 h (California Rare Fruit Growers, 1996). Fig plants will survive as far north as New Jersey in protected areas such as south-facing walls of houses, and can tolerate temperatures as low as $-10{ }^{\circ} \mathrm{C}$ (California Rare Fruit Growers, 1996). Many cultivars require lots of heat units to achieve good fruit quality and are never acceptable in cool climates like coastal California (California Rare Fruit Growers, pers. comm.). Commercial production is concentrated in dry hot summer climates and fig is extremely drought tolerant once established, but needs regular watering during establishment and achieves greater 


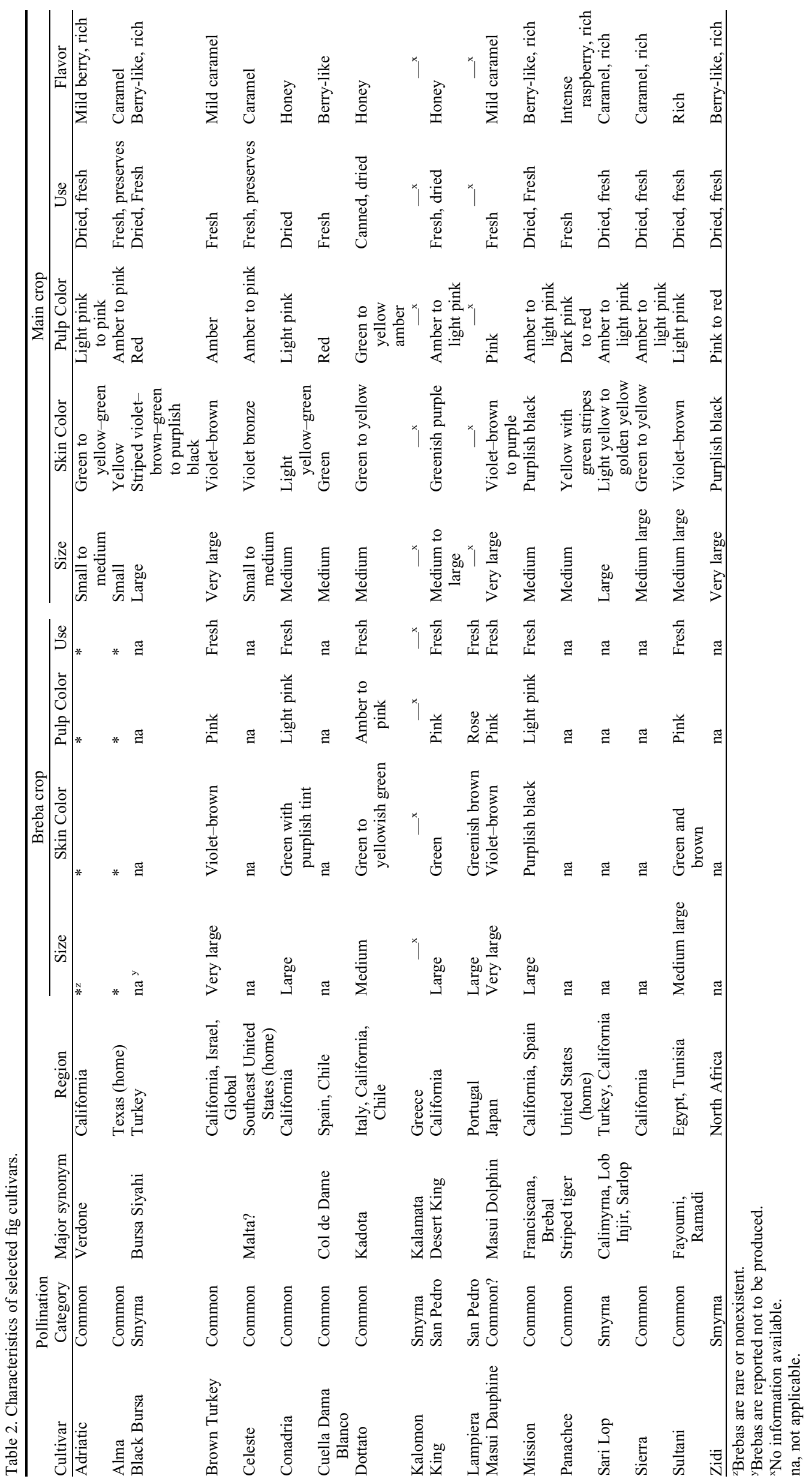


Table 3. Percentage persistent figs in progeny based on genotypes of pollen and seed parents (Saleeb and Storey, 1975).

\begin{tabular}{lcr}
\hline & \multicolumn{2}{c}{ Seed Parent } \\
\cline { 2 - 3 } Pollen parent & $+/+$ & $+/ \mathrm{P}$ \\
\hline$+/+$ & $0 \%$ & $50 \%$ \\
$+/ \mathrm{P}$ & $0 \%$ & $50 \%$ \\
\hline,+ wild-type allele for caducous & syconia and \\
normal ovules; P, dominant mutant allele for \\
persistent syconia but lethal in ovule.
\end{tabular}

yields when irrigated. In irrigated orchards, water supply is reduced in the weeks before maturity for dried-fruit production, but is maintained for fresh production. Fig thrives on soils ranging from light sand to heavy clay or limestone (Morton, 1987).

Figs root easily from cuttings and this is the standard method of propagation worldwide. In Florida (Krezdorn and Glasgow, 1970) and the Philippines (De La Cruz and Gonzalez, 1953), grafting $F$. carica to the rootstock of other species has been demonstrated. Topworking trees to more desirable varieties can be done with a variety of budding and grafting methods (Morton, 1987). In California there are unpublished reports of budding $F$. carica to different rootstocks of the same species for size control or manipulation of fruit maturity (California fig growers, pers. comm.).

New fig plantations are typically established after 12 to 15 months in the nursery and will set some fruit the following year (Morton, 1987), but generally reach good commercial production in 3 to 5 years. Fig orchards do not require regular fertilization unless grown on sand, and excessive application will encourage plant growth at the expense of fruit production. No more than 0.2 to $0.5 \mathrm{~kg} \mathrm{~N}$ should be applied per tree per year, with split applications from early spring through July (Morton, 1987). Nitrogen is the only nutrient that is regularly applied to fig orchards.

Orchards for dried-fig production in California are typically planted in a wide spacing (6-12 $\mathrm{m}$ between trees), receive pruning to sustain adequate annual growth, and figs are harvested from the manicured orchard floor after abscission (Ferguson et al., 1990). Figs for fresh fruit production in California are topped to permit harvest with minimal ladder work, and are sometimes planted at much higher densities, including trellising in a "cordon" production system similar to that for grape (California fig growers, pers. comm.). With aggressive management, this cordon system can be used to produce two main crops per year in regions with yearround warmth (Israeli fig growers, pers. comm.). When pruning figs, special care must be taken if breba production is important, because these fruit grow on the previous season's wood.

Production of quality fresh figs outside the peak harvest season results in premium prices. For this reason, some growers manipulate time of budbreak by timing pruning, control of irrigation, and use of hydrogen cyanamide (e.g., Norberto et al., 2001).
Earlier maturation and abscission of dried figs permits harvest before there is a significant risk of rain. Carefully timed Ethephon applications may be used to help accelerate this process (Morton, 1987).

\section{PESTS AND DISEASES}

Nematodes in the genus Meloidogyne may be the most important and widespread pest of fig (McBeth, 1949). Figs have few other routinely serious pests or diseases except where rain is common in summer. Even commercial fig orchards in California rarely receive pesticide sprays. Arthropod pests are sporadically important and include dried-fruit pests like the coleopteran Carpophillus hemipterous and lepidopteran Ephestia figulilella (reviewed in Ferguson et al., 1990). In high summer rainfall regions, fruit splitting is common and fungicides may be necessary to control Alternaria, Aspergillus, Botrytis, and Penicillium fungi (Tous and Ferguson, 1996).

Alternaria and Fusarium are especially noteworthy for producing internal fruit rot and are the primary fungal concerns in California fig production, whereas other diseases may be important in some orchards in individual years (reviewed in Ferguson et al., 1990). Endosepsis, also called pink/brown/ soft/eye-end rot, is caused primarily by F. moniliforme pv. Fici (Ferguson et al., 1990 ), and formerly resulted in $30 \%$ to $50 \%$ crop loss in some California orchards (Hansen, 1928). The fungus is maintained in consecutive fruit stages of caprifig trees and is introduced into edible figs by female fig wasps. This problem is a major reason for the California shift away from varieties requiring pollination.

Aflatoxin, a mycotoxin produced during A. flavus infection, is sometimes detected in dried figs. This compound is a potent carcinogen and is subject to monitoring and product rejection at very low thresholds by the Food and Drug Administration. Infection is thought to occur during sun-drying of figs on trees, but despite the routine use of this practice, aflatoxin incidence in figs is very low (Buchanan et al., 1975). Even though this problem is rare, detection and reducing formation of mycotoxins in figs are active areas of research (e.g., Karaca and Sebahattin, in press).

Worldwide, fig mosaic disease (FMD) is a concern, producing typical mosaic virus symptoms of yellow rings on leaves and sometimes symptoms on fruit. Stunting of trees and reduced productivity are associated with severe foliar symptoms (California fig growers, pers. comm.). Although FMD is believed to cause significant economic losses, it is difficult to assess (Condit, 1941). The causal agent of FMD has never been confirmed, although it is likely a virus or complex of viruses thought to be vectored by the mite Aceria ficus (Serrano et al., 2004). Use of shoot-tip culture and thermotherapy reduce or eliminate symptoms (Gella et al., 1998).

\section{THE FUTURE}

As a complement to the rich pleasures of dried figs and their products, there is a great deal of interest in expanding fresh fig sales in the United States and around the world. This will require significant advances in postharvest handling. Based on our experience with naive consumers, the potential customer base for fresh figs is very large. Visitors to the National Clonal Germplasm Repository in Davis, CA, are astounded by the bright fruity flavors, reminiscent of berries or citrus, of some fresh fig varieties.

\section{Literature Cited}

Armstrong, W.P. 2006. Sex determination \& life cycle of Ficus carica. Aug. 2006. <http:// waynesword.palomar.edu/pljun99b.htm>.

Beck, N.G. and E.M. Lord. 1988. Breeding system in Ficus carica, the common fig. I. Floral diversity. Amer. J. Bot. 75:1904-1912.

Bostock, J. and H.T. Riley (trans.). 1855. Pliny the Elder: The natural history, Book 23, Chapter 63. Taylor and Francis, London.

Buchanan, J.R., N.F. Sommer, and R.J. Fortlage. 1975. Aspergillus flavus infection and aflatoxin production in fig fruits. Appl. Microbiol. 30:238-241.

Chessa, I. 1997. Fig, p. 245-268. In: S. Mitra (ed.). Postharvest physiology and storage of tropical and subtropical fruits. CAB International, Wallingford, UK.

California Fig Advisory Board. 2006. Varietal info. Aug. 2006. <www.californiafigs.com/about/ index.html>.

California Fresh Fig Growers Association. 2006. Seasons and varieties. Aug. 2006. <www. calfreshfigs.com/seasons.html $>$.

California Rare Fruit Growers. 1996. Fig. Aug. 2006. <www.crfg.org/pubs/ff/fig.html >.

Condit, I.J. 1932. The structure and development of flowers in Ficus carica L. Hilgardia 6:443-481.

Condit, I.J. 1941. Fig culture in California. Calif. Agr. Ext. Serv. Circ. 77. Berkeley, CA.

Condit, I.J. 1947. The fig. Chronica Botanica Co. Waltham, MA.

Condit, I.J. 1955. Fig varieties: A monograph. Hilgardia 23:323-538.

Condit, I.J. 1969. Ficus: The exotic species. University of California, Division of Agricultural Sciences. Berkeley, CA.

Crane, J.C. and R. Blondeau. 1949. The use of growth-regulating chemicals to induce parthenocarpic fruit in the Calimyrna fig. Plant Physiol. 24:44-53.

De Candolle, A. 1886. Origin of cultivated plants (reprint of 2nd edition, 1967). Hafner Publishing, New York.

De La Cruz, E. and L.G. Gonzalez. 1953. The graft affinity of the fig, Ficus carica, with some of its congeners. Philipp. Agr. 37:119-129.

Doster, M.A., T.J. Michailides, and D.P. Morgan. 1996. Aspergillus species and mycotoxins in figs from California orchards. Plant Dis. 80:484-489.

Doyle, J. and L. Ferguson. 1997. Breeding persistent figs with Calimyrna quality. Acta Hort 480:259-264.

FAO. 2006. FAOSTAT agricultural data. Aug. 2006. $<$ http://faostat.fao.org/site/408/default.aspx>.

Ferguson, L., T.J. Michailides, and H.H. Shorey. 1990. The California fig industry. Hort. Rev. (Amer. Soc. Hort. Sci.) 12:409-490.

Hansen, H.N. 1928. Endosepsis and its control in caprifigs. Phytopathology 18:931-938. 
Gella, R., J.A. Marin, M.L. Corrales, and F. Toribio. 1998. Elimination of fig mosaic from fig shoot-tip cultures by thermotherapy. Acta Hort. 480:173-177.

Karaca, H. and N. Sebahattin. (in press). Mycotoxins in dried figs. Proc. Third Int. Fig Symp.

Kjellberg, F., P.H. Gouyon, M. Ibrahim, M. Raymond, and G. Valdeyron. 1987. The stability of the symbiosis between dioecious figs and their pollinators: A study of Ficus carica L. and Blastophaga psenes L. Evolution Int. J. Org. Evolution 41:693-704.

Krezdorn, A.H. and S.K. Glasgow. 1970. Propagation of Ficus carica on tropical species of Ficus. Proc. Tropical Region Amer. Soc. Hort. Sci. 14:156-164.

McBeth, C.W. 1949. Nematodes affecting figs, p. 16-17. In: 3rd Ann. Res. Conf. Calif. Fig Inst. Proceed.
Michailides, T.J., D.P. Morgan, and K.V. Subbarao. 1996. An old disease still a dilemma for California growers. Plant Dis. 80:828-841.

Morton, J. 1987. Fig, p. 47-50. In: Fruits of warm climates. Julia F. Morton, Miami, FL.

Norberto, P.M., N.N.J. Chalfun, M. Pasqual, R.D. Veiga, and J.H. Mota. 2001. Efeito de epoca de poda, cianamida hidrogenada e irrigacao na producao antecipada de figos verdes. Pesquisa Agropecuaria Brasileira. 36:13631369.

Obenauf, G., M. Gerdts, G. Leavitt, and J. Crane. 1978. Commercial dried fig production in California. Univ. of Calif. Agr. Ext. Leaflet 21051, Oakland, CA.

Saleeb, W.F. and W. Storey. 1975. The genetics of persistent vs. caducous synconia in fig. HortScience 10:328.
Schwaez, O. 1933. Beitrage zur Pathologie der Feige, Ficus carica ii. I. Das Frachtfauleproblem in Kleinasien. Phytopath. Zeitschr. 6:589-618.

Serrano, L., J. Ramon, J. Segarra, V. Medina, M.A. Achon, M. Lopez, and M. Juarez. 2004. New approach in the identification of the causal agent of fig mosaic disease. Acta Hort. 657:559-566.

Storey, W.B. 1975. Figs, p. 568-588. In: J. Janick and J.N. Moore (eds.), Advances in fruit breeding. Purdue University Press, West Lafayette, IN

Tous, J. and L. Ferguson. 1996. Mediterranean fruits, p. 416-430. In: J. Janick (ed.), Progress in new crops. ASHS Press, Arlington, VA.

Zohary, D. and P. Spiegel-Roy. 1975. Beginnings of fruit growing in the old world. Science 187:319-327. 